$10-20-2014$

\title{
Lake Flooding and Synoptic Weather-type Frequency At Devils Lake, North Dakota, USA, Between 1965 and 2010
}

Paul E. Todhunter

University of North Dakota, paul.todhunter@und.edu

Emily A. Knish

\section{How does access to this work benefit you? Let us know!}

Follow this and additional works at: https://commons.und.edu/geo-fac

Part of the Geography Commons

\section{Recommended Citation}

Paul E. Todhunter and Emily A. Knish. "Lake Flooding and Synoptic Weather-type Frequency At Devils Lake, North Dakota, USA, Between 1965 and 2010" (2014). Geography \& Geographic Information Science Faculty Publications. 5.

https://commons.und.edu/geo-fac/5

This Article is brought to you for free and open access by the Department of Geography \& Geographic Information Science at UND Scholarly Commons. It has been accepted for inclusion in Geography \& Geographic Information Science Faculty Publications by an authorized administrator of UND Scholarly Commons. For more information, please contact und.commons@library.und.edu. 


\title{
Lake flooding and synoptic weather-type frequency at Devils Lake, North Dakota, USA, between 1965 and 2010
}

\author{
Paul E. Todhunter*, Emily A. Knish \\ Department of Geography, University of North Dakota, Grand Forks, North Dakota 58202-9020, USA
}

\begin{abstract}
Since the spring of 1993, the water surface elevation at Devils Lake, a terminal lake in eastern North Dakota, USA, has risen by $8.8 \mathrm{~m}$, producing more than 1 billion USD in direct flood damages. We examine the relationship between weather-type frequencies at Bismarck, North Dakota, and lake volume changes from 1965 to 2010 using the Spatial Synoptic Classification (SSC) system. First, we find statistically significant changes in the frequency of selected weather types over both annual and seasonal time periods. This indicates a trend toward increased advection of more humid weather types that is consistent with the historical rise in lake level. Second, a comparison of weather type frequencies between a subset of years with extreme large and small lake surges, and extreme large and small lake drawdowns, shows that weathertype frequency plays an important role in explaining annual lake volume fluctuations. The results support a climatic explanation for the historical lake rise at Devils Lake, but the relationships are not as strong as might have been anticipated given the unprecedented lake rise that occurred during the study period. A more detailed examination of the complex and non-linear nature of the lake water balance may be needed to further clarify how precipitation input is translated into lake volume changes.
\end{abstract}

KEY WORDS: Devils Lake · North Dakota $\cdot$ Spatial Synoptic Classification system $\cdot$ Lake volume Lake flooding Resale or republication not permitted without written consent of the publisher

\section{INTRODUCTION}

Terminal lakes are among the world's most dynamic natural hydrological systems, with water surface elevation (WSE) often changing rapidly in response to variations in the volume of lake water sources and sinks (Williams 1996). They are also extremely sensitive to human modification of basin hydrology and can experience significant WSE changes due to alteration of basin land use/land cover and river hydrology (Coe \& Foley 2001, Williams 2002, Micklin 2007).

Devils Lake, located in the Devils Lake closed subbasin in eastern North Dakota, USA, is a particularly interesting terminal (saline) lake (Fig. 1). The lake is of glacial origin, is located along a subhumid hydroclimatic boundary, and has experienced catastrophic flooding over the past 2 decades (Bluemle \& Clayton 1984, Larson 2012). From the spring of 1993 through August 2012, the lake WSE rose by more than $8.8 \mathrm{~m}$ (Fig. 2), lake area expanded by $265 \%$, and lake volume increased by $430 \%$. Direct federal and state payments for flood damages due to the expanding lake have totaled nearly 1 billion USD (Federal Interagency Working Group 2010), although actual flood damages are generally underestimated (Smith \& Katz 2013). The Devils Lake flood catastrophe has generated considerable popular media coverage (Hamilton 2011a,b,c, Larson 2012) but only limited recent scientific investigation. The US Geological Survey (USGS) also has complete tables of lake bathymetry (lake level, area, volume relationships) for the lake, which is not common for terminal lakes. 


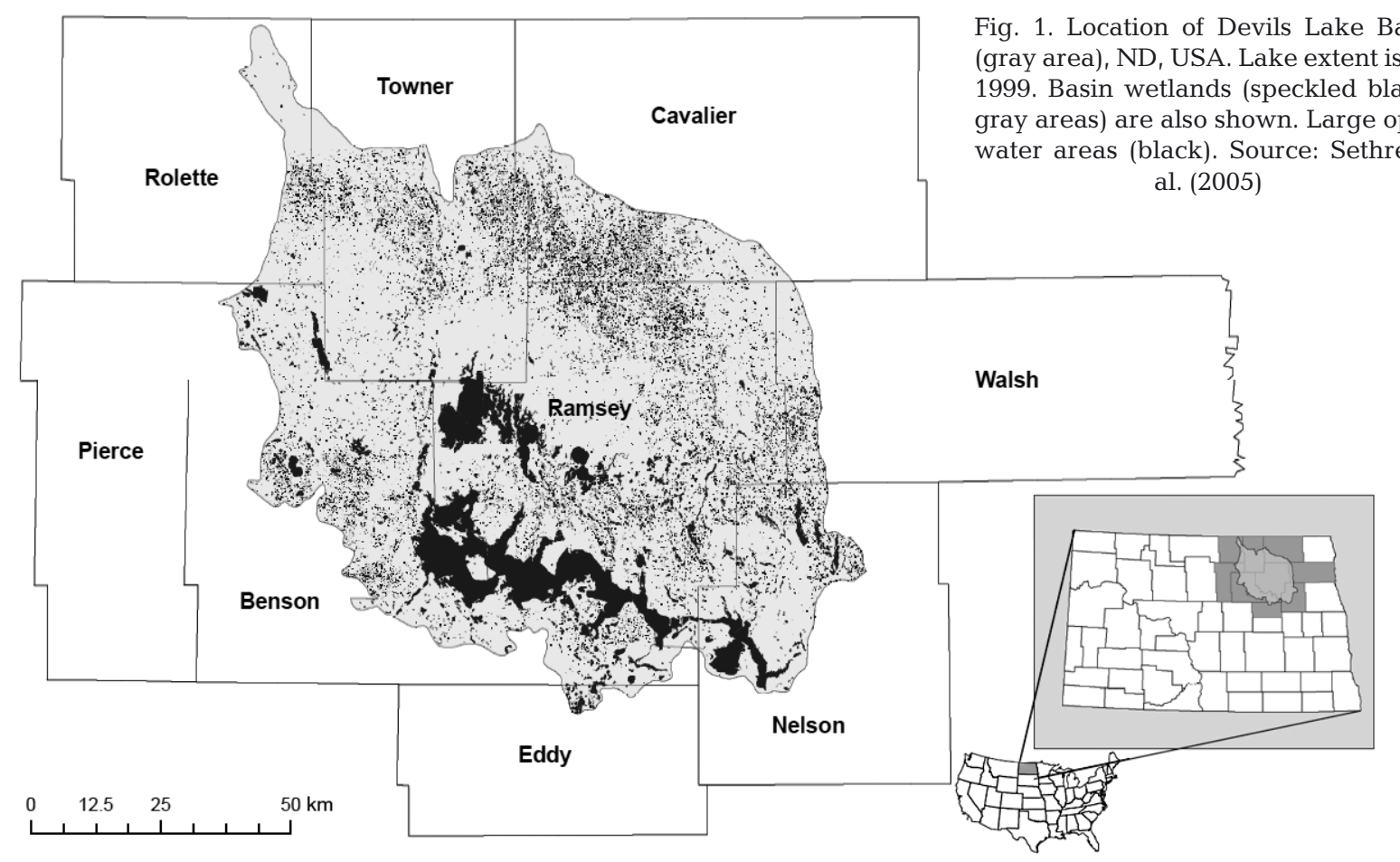

WSE at Devils Lake has fluctuated between extremes of having gone completely dry to having spilled over to the Red River of the North multiple times over the past $4000 \mathrm{yr}$ due to natural long-term climate fluctuations (Bluemle et al. 1999). Preliminary climatological investigations suggest that natural hydro-climatic variability is the most likely proxi-

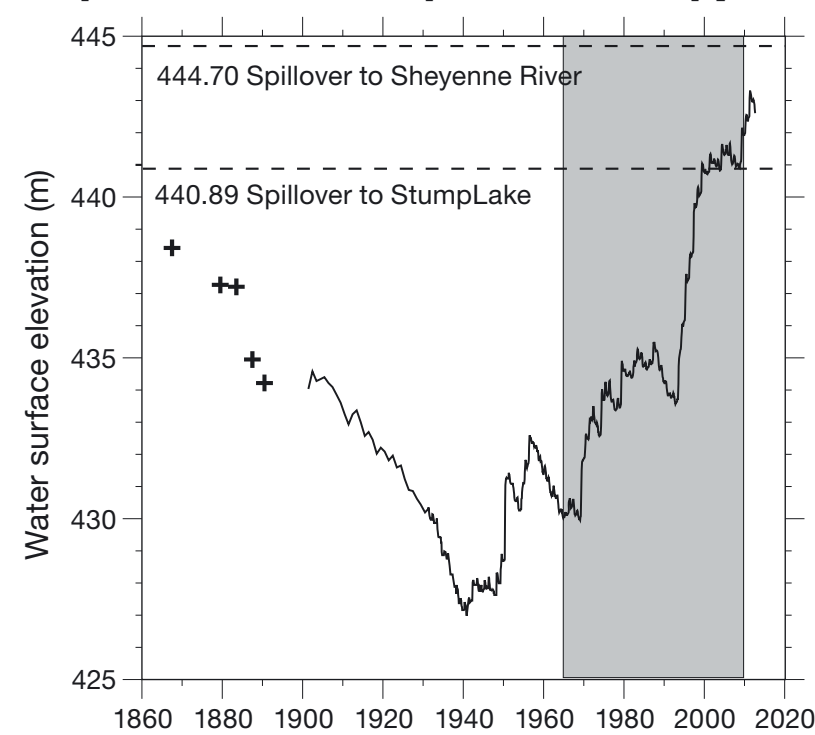

Fig. 2. Water surface elevation (m a.s.l.) time series at Devils Lake, ND, USA, through 31 August 2012. The shaded area identifies the study period covered by the Spatial Synoptic Classification analysis (SSC). Source: USGS (2012). +: early spot measurement mate cause of the recent lake rise (Hoerling et al. 2010). However, a vocal minority of local stakeholders has gathered much regional support for their assertion that wetland and agricultural drainage in the upper basin has been the leading cause for the dramatic lake rise.

A historical analysis of the lake fluctuations at Devils Lake is hindered by a lack of long-term, serially complete, quality-assured climatic and hydrological data within or closely adjacent to the Devils Lake Basin. Alternative data sets might prove useful in supplementing these more traditional data sources, and in providing insights to the cause of the lake rise. Nearly all local- and regional-scale extreme flood events and anomalies have a strong association with recognizable anomalous circulation patterns (Hirschboeck 1987). The sudden rise in WSE at Devils Lake that began in 1993, for example, exhibited a strong correlation between extreme precipitation delivery and persistent anomalous circulation patterns (Bell \& Janowiak 1995). The recent lake expansion of Devils Lake, therefore, should exhibit a clear association with atmospheric circulation anomalies and air mass and weather-type frequencies if hydroclimatic variability is the primary driver of the lake rise.

The purpose of this study is to examine the role of climate forcing upon the recent lake expansion at Devils Lake using a weather-type classification system to examine the relationship between climatic cir- 
culation patterns and historical lake volume changes. We examine 2 research questions concerning the link between lake fluctuations and weather-type variations. First, is there a significant long-term trend in the frequency of weather-type classes that is consistent with the long-term increase in lake volume? Second, is there a significant relationship between anomalous lake volume fluctuations and the relative frequency of the weather types?

\subsection{Background}

\subsubsection{Precipitation-runoff volume relationships}

Human modification of the surface landscape and river hydraulics has impacted nearly every component of continental aquatic systems (Meybeck 2003). The temperate grassland biome of the Devils Lake basin is one of the most transformed North American biomes, so human modification of the basin hydrology is certain. The relative contribution of climate variability and land cover change upon basin hydrology is scale-dependent (Blöschl et al. 2007), and the moderate size of the Devils Lake basin $\left(9868 \mathrm{~km}^{2}\right)$ is consistent with both factors being potentially significant driving factors impacting basin runoff volume (Chang \& Franczyk 2008).

Identifying the impact of individual land cover and hydrologic changes upon basin flooding and runoff volume is problematic, since multiple factors interact in non-linear and scale-dependent relationships (Blöschl et al. 2007, Chang \& Franczyk 2008). Frans et al. (2013) used a macroscale hydrology model to show that climate change was the dominant driver of runoff volume trends in the Upper Mississippi River basin during the 20th century. Using an ecohydrological modeling approach, Tomer \& Schilling (2009) showed that climate change was a larger driver of hydrological response than land cover change. A land surface/ecosystem model was used by Twine et al. (2004) to examine the effects of historical land cover change upon the regional energy and water balances in the same area; they concluded that conversion of forest cover to cropland led to a regional increase in runoff volume. Zhang \& Schilling (2006) and Schilling et al. (2010) found that $30 \%$ of the runoff volume increase in the Mississippi River basin since the 1940s could be explained by row crop expansion, while Raymond et al. (2008) concluded that land use and land management changes were the primary drivers of increased runoff volume in the Mississippi River basin. Finally, the extensive drainage of prairie pothole wetlands within the glaciated plains of eastern North Dakota has likely also impacted the volume of upper basin water flowing into Devils Lake (Johnson et al. 2008).

\subsubsection{Synoptic weather typing in environmental analysis}

Synoptic climatology seeks to relate atmospheric circulation patterns to the mean conditions and variability of selected surface environmental phenomena (Dayan et al. 2012). A subjective, daily weather-type classification was used by Wilby (1993) to examine the long-term response of hydrological regimes to synoptic circulation patterns. Bierly et al. (2000) used daily subjective map-pattern analysis to examine the relationship between heavy snow events and midlatitude cyclone location and intensity, while manual methods of synoptic classification have been used to examine the link between flood hazard and the frequency and persistence of daily circulation patterns (Petrow et al. 2009).

Daily circulation patterns derived from objective analyses of gridded pressure maps have been positively linked to flood discharge time series (Bárdossy \& Filiz 2005), and monthly averages of daily circulation indices have been correlated to monthly stream flow into alpine lakes (McGowan \& Sturman 1996). McCabe (1996) also used correlation and anomaly pattern analyses to identify relationships between mean winter atmospheric circulation and stream flow generation.

Sheridan (2002) developed an objective synoptic weather-type classification system that has been widely used in environmental analysis, and used it to examine the frequency distribution of weather types between 2 climatological teleconnection patterns (Sheridan 2003). The data set has also been used to study seasonal snow water equivalent (SWE) patterns across the Northern Great Plains of the USA (Grundstein 2003), temporal trends in air mass frequencies (Knight et al. 2008), and the association of weather-type frequencies with major drought episodes (Quiring \& Goodrich 2008).

\section{DATA AND METHODS}

\subsection{Surge and drawdown annual time series}

The USGS began discontinuous daily WSE observations at Devils Lake in the early 1930s, and a permanent gauge was installed in Creel Bay in 1965. On 
28 March 2005, the rising lake inundated the gauge, forcing a location change $4.02 \mathrm{~km}$ to the north along Creel Bay. The historical WSE time series is based upon an ensemble of early spot measurements, regular monthly observations, and then regular daily observations (see Fig. 2). The shaded period of Fig. 2 shows the period of regular and consistent daily observations that coincides with a period of unprecedented historical lake level rise. During this period, the lake WSE rose from 430.06 to $442.44 \mathrm{~m}(\Delta=$ $12.38 \mathrm{~m})$, lake area increased from 93.9 to $653.5 \mathrm{~km}^{2}$ $\left(\Delta=559.6 \mathrm{~km}^{2}\right)$, and lake volume increased from 0.236 to $3.798 \mathrm{~km}^{3}\left(\Delta=3.563 \mathrm{~km}^{3}\right)$.

In the north central region of the USA, soil moisture, stream discharge, and lake levels normally peak in the spring, following the melt of the seasonal snowpack, and are normally lowest in the fall, following the summer-long excess of evaporative demand over precipitation (Baker et al. 1979, Wiche 1986, Stoner et al. 1998). This characteristic seasonal hydroclimatological pattern was used to identify separate lake surge and lake drawdown time series. The method for determining the individual surge and drawdown values is illustrated in Fig. 3. Lack of serially complete daily water surface elevation data prior to 1965 led to the use of a study period from 1965 through 2010.

Daily WSE data were obtained for the $46 \mathrm{yr}$ period from 1 January 1965 to 31 December 2010 (USGS 2012). The day of the year (DOY) and WSE (m) of the maximum spring WSE and minimum autumn WSE were identified for each year. A surge is defined as

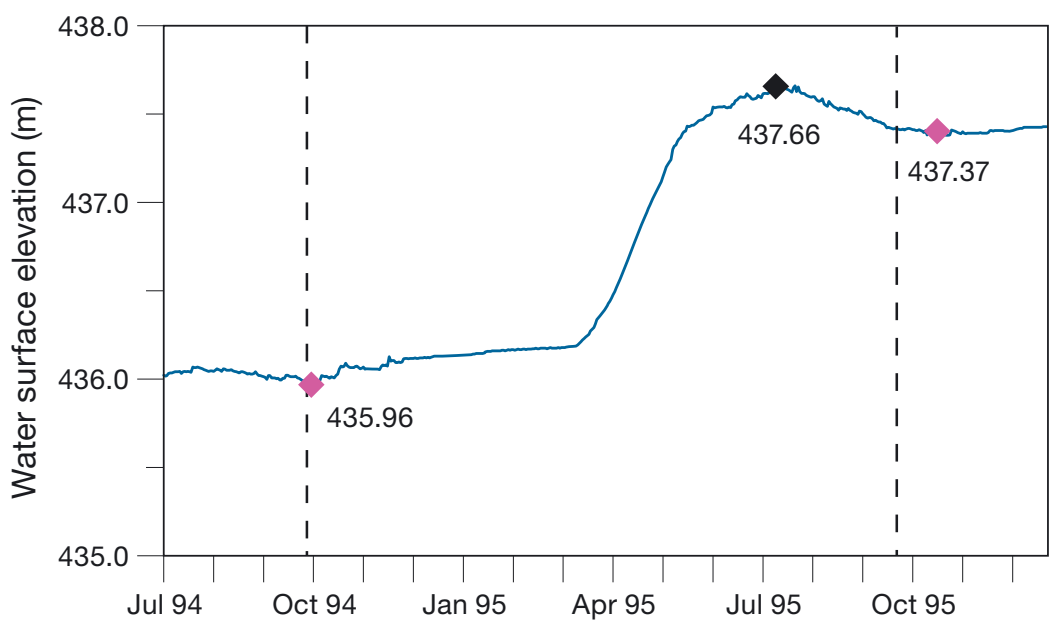

Fig. 3. Daily water surface elevation (WSE) from 1 July 1994 to 31 December 1995, with the minimum autumn (pink diamonds) and maximum spring (black diamond) WSE elevations identified to show how the surge and drawdown time series were determined. Water year 1995 illustrates a typical positive surge year and negative drawdown year. Source: USGS (2012). Dashed vertical lines separate adjacent water years (1 Oct-30 Sept) the change in WSE from the minimum autumn WSE in year $i-1$ and the maximum spring WSE in year $i$ and is calculated by taking the maximum spring WSE and subtracting the minimum autumn WSE from the previous calendar year. All 45 yr had positive surge values. The median DOY for the spring maximum WSE was 144 (24 May), with a standard deviation of $17.6 \mathrm{~d}$; the median surge value was $0.381 \mathrm{~m}\left(0.082 \mathrm{~km}^{3}\right)$.

A drawdown is defined as the change in WSE from the maximum spring WSE in year $i$ to the minimum autumn WSE in year $i$ and is calculated by subtracting the minimum autumn WSE from the maximum spring WSE of the same calendar year (Fig. 3). A total of $38 \mathrm{yr}$ had negative drawdown values, while $8 \mathrm{yr}$ had positive drawdown values, indicating a less common pattern when lake levels continue to increase throughout the summer. For this latter occurrence the DOY and WSE were set to the 30 November values. The median DOY for the autumn minimum WSE was 311 (7 November), with a standard deviation of $26.0 \mathrm{~d}_{\text {; }}$ the median drawdown value was $-0.258 \mathrm{~m}$ $\left(-0.067 \mathrm{~km}^{3}\right)$. The median surge value is greater than the median drawdown total since the study period covers a period of significant lake expansion (Fig. 2).

After the surge and drawdown WSE time series were determined, the corresponding lake volume totals were extracted from available lake bathymetry tables (North Dakota State Water Commission 2012). The water years with the 5 smallest and largest surges, and the 5 smallest and largest drawdowns, were selected from the full surge and drawdown time series for more detailed investigation. The use of a subset of years consisting of the extreme high and low lake volume totals follows the approach of Grundstein (2003) and assumes that if a significant relationship exists between lake volume fluctuations and weather-type frequency, it will be evident in the extreme years. The surge values of the 5 smallest and largest surge years were all positive. The 5 smallest drawdown values were all positive values, indicating an increase in WSE during the summer, while the 5 largest drawdown values were all negative values, indicating a summer decrease in WSE.

The selected lake volume-derived years are included in Table 1. Lake volume is examined since it is more fundamentally linked to the lake water 
Table 1. Water years selected from surge and drawdown analyses based upon changes in lake volume $\left(\mathrm{km}^{3}\right)$. Positive (negative) totals represent increases (decreases) in lake volume

\begin{tabular}{|c|c|c|c|c|c|c|c|}
\hline \multicolumn{2}{|c|}{ Small surge } & \multicolumn{2}{|c|}{ Large surge } & \multicolumn{2}{|c|}{ Small drawdown } & \multicolumn{2}{|c|}{ Large drawdown } \\
\hline Year & Volume & Year & Volume & Year & Volume & Year & Volume \\
\hline 1968 & 0.015 & 1995 & 0.418 & 1969 & 0.072 & 1988 & -0.134 \\
\hline 1973 & 0.010 & 1997 & 0.500 & 1974 & 0.038 & 1998 & -0.132 \\
\hline 1977 & 0.017 & 1999 & 0.462 & 1993 & 0.188 & 2003 & -0.183 \\
\hline 1988 & 0.000 & 2004 & 0.395 & 1994 & 0.030 & 2004 & -0.148 \\
\hline 1990 & 0.006 & 2009 & 0.663 & 1997 & 0.048 & 2006 & -0.373 \\
\hline
\end{tabular}

budget than is WSE (Mason et al. 1994, Mohammed \& Tarboton 2011). Studies of terminal lake hydrological changes are often limited to only WSE data, since WSE-lake volume (or WSE-lake area) relationships are not normally known.

\subsection{Spatial Synoptic Classification system}

The Spatial Synoptic Classification (SSC) system is a hybrid weather-type classification system originally developed for the conterminous USA. A weathertype classification has some advantages over more traditional methods of climate change and climate variability analysis that are based upon individual meteorological variables since it incorporates multiple components of surface conditions (Knight et al. 2008). SSC assigns each station day into 1 of the 6 distinct weather types or a seventh type that is a transitional type between 2 weather types. Details about the surface climate characteristics of each of the 7 weather types, and their association with common air mass source regions, are provided in Sheridan (2002).

Daily weather-type calendars for 1965 to 2010 were downloaded from the SSC website (http://sheridan. geog.kent.edu/ssc.html) for the Fargo, ND, and Bismarck, ND, first-order weather stations. The SSC data set extends to 1948, but daily WSE data only began with the 1965 water year in Devils Lake. Separate results were determined for the Fargo and Bismarck weather-type calendars, but only the Bismarck results will be presented. The mean annual match percentage between the 2 stations is about $65 \%$ (Sheridan 2002), indicating a strong spatial coherence in the weather-type occurrence for the same day between the 2 stations. The 3 moist tropical weather-type codes were merged into a single category due to the low frequency of occurrence of the additional subtypes.

\subsection{Water year, cold season, and warm season periods}

The frequency of the $7 \mathrm{SSC}$ weather types was analyzed by water year, and separate cold and warm seasons. The water year follows the standard period of 1 October to 30 September $(\mathrm{N}=45 \mathrm{yr})$, the cold season runs from 1 November through 31 March $(\mathrm{N}=45 \mathrm{yr})$, and the warm season from 1 May through 30 September $(\mathrm{N}=46 \mathrm{yr})$. These seasonal designations are consistent with the long duration of snow cover typically experienced in east central North Dakota (Wiche 1986, Grundstein 2003, Todhunter 2012). April and October were considered transitional months between the warm and cold seasons. The cold season normally has $151 \mathrm{~d}(152 \mathrm{~d}$ for leap years), while the warm season has $153 \mathrm{~d}$.

The relative frequency and climatological characteristics of the SSC weather types for Bismarck are given in Table 2 for selected weather variables. The data are averages obtained from the SSC website for the period 1936-2013. The values shown are for January and July, the middle months of the 5 mo cold and warm seasons, respectively. The relative frequency of the 7 weather types for the water year, cold season, and warm season for the study period are shown in Fig. 4.

The dry weather types for the Devils Lake basin are: (1) dry moderate (DM): mild and dry air associated with zonal flow aloft that has dried and warmed adiabatically in passage over the Rocky Mountains; (2) dry polar (DP): cool or cold dry air advected into the region as a cold-core anticyclone from northcentral Canada; and (3) dry tropical (DT): warm and dry air that is advected into the region in summer from the south and west when a stationary upperlevel ridge of high pressure is positioned over the Great Plains.

The moist weather types are: (4) moist moderate (MM): warmer and more humid than the moist polar weather type; (5) moist polar (MP): a cool and humid weather type advected to the region from the North Pacific during the transitional spring and autumn seasons when upper-level zonal flow is present; and (6) moist tropical (MT): a very warm and humid weather type advected to the basin from the Gulf of Mexico, and associated with summer convective precipitation. The final weather type is: (7) transitional (TR): occurs when one weather type transitions to a different weather type as evidenced by large 
Table 2. Spatial Synoptic Classification (SSC) station climatology for Bismarck, North Dakota, USA. The weather type frequencies are based on the percentage of all classified days over the period 1936-2013. All values are for 15:00 h local time. Source: http://sheridan.geog.kent.edu/ssc.html. n/a: not available

\begin{tabular}{|c|c|c|c|c|c|c|}
\hline Variable & $\begin{array}{c}\text { Frequency } \\
(\%)\end{array}$ & $\begin{array}{c}\text { Air temperature } \\
\left({ }^{\circ} \mathrm{C}\right)\end{array}$ & $\begin{array}{c}\text { Dew point } \\
\text { temperature }\left({ }^{\circ} \mathrm{C}\right)\end{array}$ & $\begin{array}{c}\text { Sea-level } \\
\text { pressure (mb) }\end{array}$ & $\begin{array}{l}\text { Cloud cover } \\
\text { (tenths) }\end{array}$ & $\begin{array}{l}\text { Wind speed } \\
\left(\mathrm{km} \mathrm{h}^{-1}\right)\end{array}$ \\
\hline \multicolumn{7}{|l|}{ January } \\
\hline Dry moderate & 17.5 & 3 & -4 & 1012 & 4 & 20 \\
\hline Dry polar & 47.0 & -14 & -20 & 1026 & 5 & 18 \\
\hline Dry tropical & 0.1 & $\mathrm{n} / \mathrm{a}$ & $\mathrm{n} / \mathrm{a}$ & $\mathrm{n} / \mathrm{a}$ & $\mathrm{n} / \mathrm{a}$ & $\mathrm{n} / \mathrm{a}$ \\
\hline Moist moderate & 7.4 & 1 & -3 & 1011 & 8 & 17 \\
\hline Moist polar & 12.6 & -6 & -9 & 1016 & 9 & 17 \\
\hline Moist tropical & 0.0 & $\mathrm{n} / \mathrm{a}$ & $\mathrm{n} / \mathrm{a}$ & $\mathrm{n} / \mathrm{a}$ & $\mathrm{n} / \mathrm{a}$ & $\mathrm{n} / \mathrm{a}$ \\
\hline Transitional & 15.4 & -9 & -14 & 1017 & 7 & 24 \\
\hline \multicolumn{7}{|l|}{ July } \\
\hline Dry moderate & 40.2 & 29 & 12 & 1014 & 4 & 19 \\
\hline Dry polar & 12.5 & 23 & 10 & 1018 & 6 & 18 \\
\hline Dry tropical & 7.9 & 35 & 11 & 1010 & 3 & 22 \\
\hline Moist moderate & 7.6 & 23 & 16 & 1012 & 8 & 20 \\
\hline Moist polar & 5.8 & 19 & 13 & 1016 & 9 & 17 \\
\hline Moist tropical & 18.6 & 31 & 18 & 1009 & 4 & 19 \\
\hline Transitional & 9.2 & 28 & 13 & 1010 & 5 & 26 \\
\hline
\end{tabular}

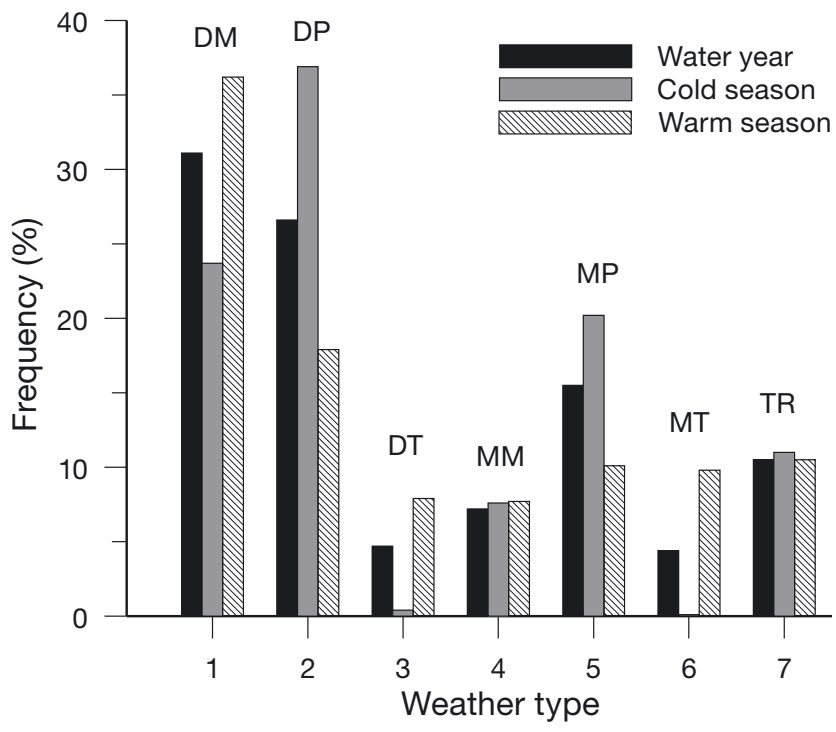

Fig. 4. Histogram of weather-type frequencies (\% of day in the year) for Bismarck, ND, USA, for the study period 1965-2010. The periods are the water year (Oct-Sep), cold season (Nov-Mar), and warm season (May-Sep). DM: dry moderate; DP: dry polar; DT: dry tropical; MM: moist moderate: MP: moist polar; MT: moist tropical; TR: transitional

changes in surface characteristics. This is often associated with the occurrence of a frontal passage.

An annual time series of precipitation amount was developed for the water year, cold season, and warm season for the study period from the PRISM data set (Daly et al. 2008) to establish basic relationships between precipitation amount and the surge and drawdown annual time series (see Section 2.1). The coor- dinates of the USGS lake level recording station were used to create the PRISM data set. Use of a point precipitation time series is justified since the USGS station is centrally located within the lake system, direct precipitation onto the lake surface is the single largest input to lake volume (Mason et al. 1994), climatic normal precipitation isohyets vary slowly across the region (Rosenberg 1986), and lake area comprised only $7.6 \%$ of the Devils Lake subbasin even at peak lake extent.

\subsection{Statistical tests}

Standard linear regression analysis was used to test for the presence of a long-term trend in the frequency of the 7 SSC weather types over the study period. The year 2007 was excluded from the analysis for all 3 time periods due to missing SSC data. Given the magnitude of the WSE increase during 1965-2010, we would expect to find an increase (decrease) in the frequency of humid and transitional (dry) weather types over the study period.

A chi-square test was used to compare the observed and expected frequencies of the weather types during the cold (warm) season months for the 5 years with the largest and smallest surges (drawdowns). The null hypothesis is that the observed frequencies of the individual weather types within the large and small surge and drawdown years match the expected frequency of occurrence for each weather type within the cold or warm season for the period of record. We anticipate that years with a large draw- 

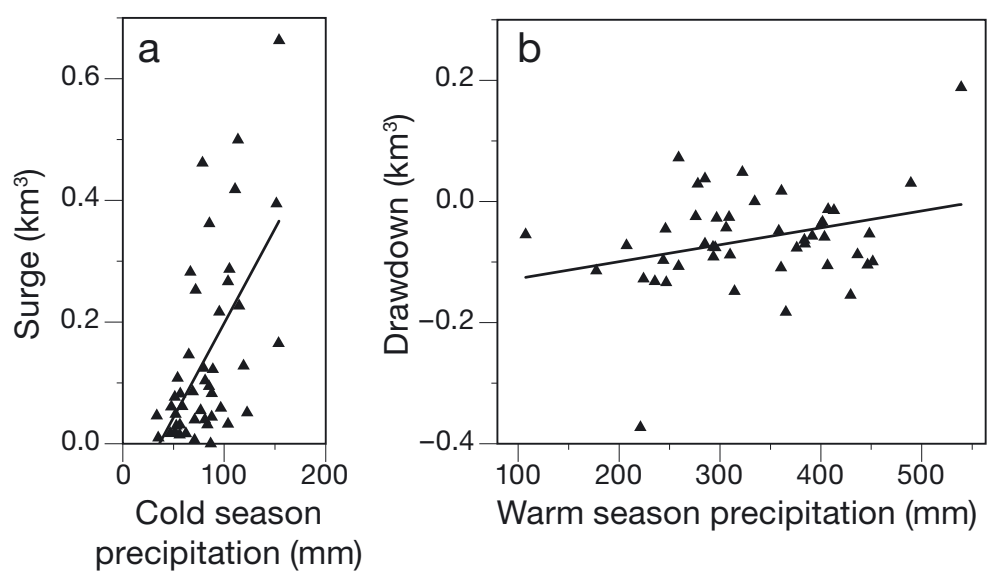

Fig. 5. Scatter plot of (a) lake surge versus cold season precipitation amount $(\mathrm{N}=45)$ and (b) lake drawdown versus warm season precipitation amount $(\mathrm{N}=46)$ for the study period

down or small surge should contain a higher frequency of drier weather types and fewer occurrences of humid and transitional weather types. Years with a large surge or small drawdown are expected to have a higher frequency of humid and transitional weather types and fewer occurrences of dry weather types. A 0.05 level of significance is used for the test statistic.

\section{RESULTS}

\subsection{Surge-drawdown precipitation relationships}

Pearson correlation analysis of the relationships between cold season precipitation and lake surge $\left(\mathrm{km}^{3}\right)$, and between warm season precipitation and lake drawdown $\left(\mathrm{km}^{3}\right)$, are shown in Fig. 5. A significant positive relationship exists between cold season precipitation and lake surge $\left(\mathrm{R}^{2}=0.35, \mathrm{p}<0.01\right)$. Cold season precipitation varies by a factor of nearly 5 , from 33 to $154 \mathrm{~mm}$, while lake surge varies by nearly 2 orders of magnitude, ranging from $<0.001$ to $0.663 \mathrm{~km}^{3}$. Cold season precipitation amount is clearly an important driver of lake surge, although other factors, such as fall soil moisture content, frost depth, and the duration and rate of the spring thaw, appear to also play important roles (Todhunter 2001).

A significant positive relationship also exists between warm season precipitation and drawdown $\left(\mathrm{R}^{2}=0.09, \mathrm{p}<0.05\right)$, although the relationship is noticeably weaker. Warm season precipitation also varies by a factor of 5, from 107 to $539 \mathrm{~mm}$, while drawdown ranges from -0.373 to $0.188 \mathrm{~km}^{3}$. Dry summers are associated with large drawdowns, while wetter summers produce smaller drawdown values.
Wet summers reduce lake evaporation due to increased cloud cover, increase the direct precipitation onto the lake surface, and therefore reduce the net evaporation from the lake (Wiche 1986).

\subsection{Trend analysis of SSC weather types}

The regression coefficients for the trend analysis of each weather type for the 3 time periods are summarized in Table 3 . The regression coefficient indicates the change in the number of days of a weather-type occurrence per year (Vanos \& Cakmak 2014). Results from the water year analysis show a statistically significant increase in the frequency of the DM and MT weather types and statistically significant decreases in the frequency of the DP and TR weather types. For the cold season, there is a significant increase in the occurrence of the DM weather type and significant decreases in the occurrence of the DP and TR weather types. Warm season results indicate significant increases in the occurrence of the DM and MT weather types and a significant decrease in the occurrence of the TR weather type (Table 3 ).

\subsection{Chi-square analysis of SSC weather types}

\subsubsection{Individual extreme surge and drawdown years}

Expected values of weather types were calculated for the cold and warm seasons by taking the frequency of each weather type during each season. The results of the chi-square analysis between the

Table 3. Summary of linear regression analysis results of Spatial Synoptic Classification (SSC) weather-type frequency trends over the period 1965-2010. Regression coefficient units are $\mathrm{d} \mathrm{yr}^{-1} .{ }^{*} \mathrm{p}<0.05$

\begin{tabular}{|lccc|}
\hline Weather type & $\begin{array}{c}\text { Water } \\
\text { year }\end{array}$ & $\begin{array}{c}\text { Cold } \\
\text { season }\end{array}$ & $\begin{array}{c}\text { Warm } \\
\text { season }\end{array}$ \\
\hline Dry moderate & $0.414^{*}$ & $0.255^{*}$ & $0.124^{*}$ \\
Dry polar & $-0.376^{*}$ & $-0.311^{*}$ & -0.045 \\
Dry tropical & -0.102 & -0.000 & -0.067 \\
Moist moderate & 0.084 & 0.072 & -0.008 \\
Moist polar & 0.003 & 0.056 & -0.053 \\
Moist tropical & $0.105^{*}$ & 0.001 & $0.110^{*}$ \\
Transitional & $-0.300^{*}$ & $-0.144^{*}$ & $-0.096^{*}$ \\
\hline
\end{tabular}


Table 4. Results of chi-square analysis for the observed and expected synoptic weather-type frequencies for the 5 smallest and largest surge and drawdown years determined by volume changes. ${ }^{*} \mathrm{p}<0.05$

\begin{tabular}{|ccccccccc|}
\hline \multicolumn{2}{c}{ Smallest surge } & \multicolumn{2}{c}{ Largest surge } & \multicolumn{3}{c}{ Smallest drawdown } & \multicolumn{2}{c|}{ Largest drawdown } \\
Year & $\chi^{2}$ & Year & $\chi^{2}$ & Year & $\chi^{2}$ & Year & $\chi^{2}$ \\
\hline 1968 & 6.32 & 1995 & $22.59^{*}$ & 1969 & 7.56 & 1988 & $65.94^{*}$ \\
1973 & $21.56^{*}$ & 1997 & $12.77^{*}$ & 1974 & $19.98^{*}$ & 1998 & $29.66^{*}$ \\
1977 & 8.94 & 1999 & $19.14^{*}$ & 1993 & $40.83^{*}$ & 2003 & $26.72^{*}$ \\
1988 & 4.99 & 2004 & $10.52^{*}$ & 1994 & 7.34 & 2004 & $13.11^{*}$ \\
1990 & $19.58^{*}$ & 2009 & 3.69 & 1997 & $25.08^{*}$ & 2006 & $53.09^{*}$ \\
\hline
\end{tabular}

explain this result. The increased advection of more humid air masses to the Devils Lake region found in the present study is consistent with the historical rise in lake levels (Fig. 2), and the association of large seasonal precipitation amounts with larger spring surges and smaller warm season drawdowns (Fig. 5). The present study and that of Knight et al. (2008) both found a decrease in the frequency of the TR weather observed and expected synoptic weather-type frequencies for the 5 smallest and 5 largest surge and drawdown years are given in Table 4 . The chi-square results for the smallest surge years led to rejection of the null hypothesis for 2 years $(1973,1990)$, while the largest surge year results indicate rejection of the null hypothesis for years 1995, 1997, 1999, and 2004. For the smallest drawdown years, the chi-square results lead to rejection of the null hypothesis for 3 years $(1974,1993$, and 1997), while the null hypothesis is rejected for all 5 of the largest drawdown years (1988, 1998, 2003, 2004, and 2006).

\subsubsection{Composite extreme surge and drawdown years}

Chi-square analyses were determined for the composite observed synoptic weather-type frequencies obtained from the 5 smallest and largest surge years (Table 5), and the 5 smallest and largest drawdown years (Table 6). The null hypothesis of no difference in the observed and expected frequencies for years identified by lake volume changes is rejected for the smallest surge and largest drawdown composites.

\section{DISCUSSION}

The observed trends in the annual period weathertype frequencies at Bismarck for the years 1965-2010 were only moderately consistent with the results obtained by Knight et al. (2008) for the period 19482005. Knight et al. (2008) also found statistically significant increases in the frequency of warmer and more humid weather types (MM, MT, and MP) and statistically significant decreases in the frequency of the cold and dry (DP) weather type for the Midwest USA $_{i}$ however, their trends for the Bismarck station did not match those obtained in the present study. The different study periods used in the 2 studies may type for Bismarck, which suggests fewer frontal passages. This seems counterintuitive and inconsistent with the observed lake rise. Hondula \& Davis (2011) examined the wintertime decrease in the frequency of the TR weather type, however, and found that it was more directly tied to a decreasing trend in dew point temperature range, causing fewer days to be selected as a TR weather type. Thus, the decreasing frequency of the TR weather type may be more closely tied to the methodology by which days are delineated into weather types in the SSC data set than to an actual decrease in the number of frontal passages.

The cold and warm season weather-type trends are generally similar to the water year results in both sign and level of significance (Table 3). The cold sea-

Table 5. Composite observed, expected and residual frequencies for the 7 Spatial Synoptic Classification (SSC) weather types during the cold season for the 5 smallest and largest surge years. Chi-square statistics $\left(\chi^{2}\right)$ are given for each comparison. ${ }^{*} \mathrm{p}<0.05$

\begin{tabular}{|lcrr|}
\hline Weather type & Observed & Expected & Residual \\
\hline Small surge & & & \\
Dry moderate & 208 & 179 & 29 \\
Dry polar & 252 & 279 & -27 \\
Dry tropical & 2 & 3 & -1 \\
Moist moderate & 76 & 58 & 18 \\
Moist polar & 127 & 153 & -26 \\
Moist tropical & 3 & 1 & 2 \\
Transitional & 89 & 84 & 5 \\
& $22 . \chi^{*}$ & & \\
Large surge & & & \\
Dry moderate & 173 & 177 & -4 \\
Dry polar & 274 & 276 & -2 \\
Dry tropical & 0 & 3 & -3 \\
Moist moderate & 47 & 57 & -10 \\
Moist polar & 172 & 151 & -1 \\
Moist tropical & 0 & 1 & -1 \\
Transitional & 82 & 83 & \\
& $\chi^{2}=8.8$ & & \\
\hline
\end{tabular}


Table 6. Composite observed, expected and residual frequencies for the 7 Spatial Synoptic Classification (SSC) weather types during the warm season for the 5 smallest and largest drawdown years. Chi-square statistics $\left(\chi^{2}\right)$ are given for each comparison. ${ }^{*} \mathrm{p}<0.05$

\begin{tabular}{|lccr|}
\hline Weather type & Observed & Expected & Residual \\
\hline Small drawdown & & & \\
Dry moderate & 267 & 277 & -10 \\
Dry polar & 159 & 137 & 22 \\
Dry tropical & 52 & 60 & -8 \\
Moist moderate & 47 & 59 & -12 \\
Moist polar & 77 & 77 & 0 \\
Moist tropical & 80 & 75 & 5 \\
Transitional & 83 & 80 & 3 \\
& $\chi^{2}=7.9$ & & \\
Large drawdown & & & \\
Dry moderate & 303 & 276 & 27 \\
Dry polar & 92 & 136 & -44 \\
Dry tropical & 107 & 60 & 47 \\
Moist moderate & 47 & 58 & -11 \\
Moist polar & 76 & 77 & -1 \\
Moist tropical & 65 & 75 & -10 \\
Transitional & 72 & 80 & \\
& $\chi^{2}=57.9^{*}$ & & \\
\hline
\end{tabular}

son shows a significant increase in the frequency of the DM weather type and significant decreases in the frequency of the DP and TR weather types. No trend is obtained for the cold season MT due to its absence during the cold season. The warm season also reveals an increase in the frequency of the DM and MT weather types and a decrease in the frequency of TR. The warm season DP trend is also negative but not significant, in part due to its much lower frequency in the warm season (Table 2). The warm season trends reveal increased advection of humid air and presumably greater cloud coverage. These effects are physically consistent with increased surface delivery of precipitation and decreased surface evaporative demand due to lower levels of net radiation and higher surface relative humidity. Both effects would contribute to the observed rise in WSE by lessening the annual warm season lake drawdown.

Weather-type frequencies for the composite small and large surge years in Table 5 show general coherence with the relationships obtained by Grundstein (2003) between weather-type frequencies and large and small SWE totals. He found that high SWE values were produced by large inputs of snow and low rates of ablation. These conditions resulted from large snowfall accumulation and low air temperatures and were associated with a large increase in the frequency of the DP weather type, smaller increases in the frequency of the MP and TR weather types, a large decrease in the frequency of DM weather type, and a small decrease in the occurrence of the MM weather type. Low SWE values were associated with low inputs of snow and high rates of ablation. These conditions resulted from small snowfall accumulation and higher air temperatures and were associated with small increases in the frequency of DM, MM, and MP and large decreases in the frequency of DP and TR. Table 5 shows that small surge years experienced increases in the frequency of DM and MM and reduced frequency of DP and MP. These patterns would lead to increases in air and dew point temperatures, with resulting increased ablation. A comparison of the observed frequencies between the composite results for the 5 largest and smallest surge events show that the large surge years have a greater frequency of polar weather types (DP and MP) and reduced frequency of moderate weather types (DM and $\mathrm{MM}$ ), which is also consistent with Grundstein (2003).

The composite drawdown results (Table 6) show a strong relationship to atmospheric demand and atmospheric moisture content. Large drawdown years show large increases in the frequency of the DT and DM weather types, a large decrease in the frequency of the DP weather type, and smaller decreases in the MM and MT weather types. Such weather-type occurrences are associated with reduced advection of atmospheric moisture, reduced precipitation, increased solar transmission, and increased vapor density deficits, all of which promote greater evapotranspiration and larger lake drawdown. A comparison between the composite observed frequencies for the 5 largest and smallest drawdown events show that the large drawdown years have an increase in the frequency of warmer and less cloudy weather types (DM and DT) and a decrease in the frequency of the DP weather type. This would result in increased advection of warmer and drier air, reduced precipitation, increased solar transmission, and increased vapor density deficits, leading to greater evaporative demand and larger lake drawdown.

The results support a climatic explanation for the historical lake rise at Devils Lake, but the relationships are not as strong as might have been anticipated given the unprecedented lake rise during the study period (Fig. 2). Several factors may help explain this finding. First, SSC is a surface weather-type classification developed originally for biometeorological applications (Sheridan 2002). Although the data set has proven to be a useful and versatile tool for a wide 
range of climatological applications, it does not directly consider upper atmospheric conditions. Dayan et al. (2012) found that upper air data are essential to identify the atmospheric circulation patterns that lead to flash floods in the Negev Desert, and the same consideration may apply to regional flooding. Warm and moist surface atmospheric conditions are correlated with surface precipitation but not sufficient to produce regional flooding. Surface weather types work in combination with upper atmospheric circulation patterns to produce regional flooding.

Second, this analysis has only examined the frequency of synoptic weather types over time. Certain synoptic weather types show a clear and direct relationship to the surface delivery of precipitation amount. Soil moisture storage, however, can amplify or attenuate surface precipitation input, leading to enhanced or lessened surface runoff response. This basin memory effect can persist for relatively long periods of time (Peterson et al. 2013). The timing and persistence of circulation patterns also plays a significant role in explaining flood hazard (Petrow et al. 2009). This is particularly true for the Devils Lake Basin, which lies along the dry-subhumid/moistsubhumid hydroclimatic boundary, where the mean runoff ratio between wet and dry spells can vary by a factor of 2, and individual water year runoff ratios can vary by a factor of 20 (Todhunter 2012).

Finally, lake volume changes respond directly to precipitation volume and not precipitation depth (Mason et al. 1994). The volume input of direct precipitation to a terminal lake water balance is the product of precipitation depth and lake area. Thus the timing of precipitation amount with respect to lake area may need to be directly examined.

\subsection{CONCLUSIONS}

Basin flooding can be caused by atmospheric conditions affecting the surface delivery of precipitation, land use/land cover changes altering the natural pathway of water through the environment and water management decisions (Peterson et al. 2013). The present study provides evidence in support of atmospheric conditions playing an important explanatory role in the historical lake rise and expansion of Devils Lake. In the future, alternate data sets and methodologies might be used to provide independent evaluations of the climatic conditions driving the lake trends (McCabe \& Wolock 2002), while ecohydrological approaches might be used to evaluate the interplay of climatic and land use/land cover drivers of hydrologic response for the lake system (Tomer \& Schilling 2009). A more detailed examination of the complexity of the lake water balance and non-linearity of basin runoff would prove helpful in further clarifying how precipitation delivery is translated into lake volume changes.

Acknowledgements. The assistance of Rick Thalacker in editing Fig. 1 is greatly appreciated.

\section{LITERATURE CITED}

Baker DG, Nelson WW, Kuehnast EL (1979) Climate of Minnesota Part XII - the hydrologic cycle and soil water. University of Minnesota, Agricultural Experiment Station, St. Paul, Min

Bárdossy A, Filiz F (2005) Identification of flood producing atmospheric circulation patterns. J Hydrol (Amst) 313: 48-57

Bell GD, Janowiak JE (1995) Atmospheric circulation associated with the Midwest floods of 1993. Bull Am Meteorol Soc 76:681-695

Bierly GD, Harrington JA Jr, Wilhelm DF (2000) Climatology of surface cyclone trajectory and intensity for heavysnow events at three Midwestern stations. Phys Geogr 21:522-537

Blöschl G, Ardoin-Bardin S, Bonell M, Dorninger M and others (2007) At what scales do climate variability and land cover change impact on flooding and low flows? Hydrol Processes 21:1241-1247

Bluemle JP, Clayton L (1984) Large-scale glacial thrusting and related processes in North Dakota. Boreas 13: 279-299

Bluemle JP, Sabel JM, Karlén W (1999) Rate and magnitude of past global climate changes. Environ Geosci 6:63-75

Chang H, Franczyk J (2008) Climate change, land-use change, and floods: toward an integrated assessment. Geogr Compass 2:1549-1579

Coe MT, Foley JA (2001) Human and natural impacts on the water resources of the Lake Chad Basin. J Geophys Res 106(D4):3349-3356

> Daly C, Halbleib M, Smith JI, Gibson WP and others (2008) Physiographically sensitive mapping of climatological temperature and precipitation across the conterminous United States. Int J Climatol 28:2031-2064

Dayan U, Tubi A, Levy I (2012) On the importance of synoptic classification methods with respect to environmental phenomena. Int J Climatol 32:681-694

Federal Interagency Working Group (2010) Report of the Federal Interagency Devils Lake Working Group. Available at http://asacw.hqda.pentagon.mil/documents/Devils LakeReportFINAL.pdf

> Frans C, Istanbulluoglu E, Mishra V, Munoz-Arriola F, Lettenmaier DP (2013) Are climatic or land cover changes the dominant cause of runoff trends in the Upper Mississippi River Basin? Geophys Res Lett 40:1104-1110

> Grundstein A (2003) A synoptic-scale climate analysis of anomalous snow water equivalent over the northern Great Plains of the USA. Int J Climatol 23:871-886

Hamilton LM (2011a) Where the road ends in water: the lake that won't stop rising. The Atlantic. www.theatlantic. com/national/archive/2011/05/where-the-roads-end-in- 
water-the-lake-that-wont-stop-rising/238848/

Hamilton LM (2011b) Flooded lives: the fight to survive Devils Lake. The Atlantic. www.theatlantic.com/national/ archive/2011/05/flooded-lives-the-fight-to-survivedevils-lake/239368/

Hamilton LM (2011c) Spirit Lake rising: living with a neverending flood. The Atlantic. www.theatlantic.com/ health/archive/2011/05/spirit-lake-rising-living-with-aneverending-flood/239644/

Hirschboeck K (1987) Catastrophic flooding and atmospheric circulation anomalies. In: Mayer L, Nash D (eds) Catastrophic flooding. Allen and Unwin, Boston, MA, p 23-56

Hoerling M, Eischeid J, Easterling D, Peterson D, Webb R (2010) Understanding and explaining hydro-climate variations at Devils Lake. NOAA Climate Assessment, NOAA. Available at www.devilslake.noaa.gov/assessments/ NOAA_Climate_Assessment_DevilsLake_July2010.pdf

Hondula DM, Davis RE (2011) Decline in wintertime air-mass transition frequencies in the USA. Clim Res 46:121-136

Johnson RR, Oslund FT, Hertel DR (2008) The past, present, and future of prairie potholes in the United States. J Soil Water Conserv 63:84A-87A

Knight D, Davis WE, Sheridan SC, Hondula DM and others (2008) Increasing frequencies of warm and humid air masses over the conterminous United States from 1928 to 2005. Geophys Res Lett 35:L10702, doi:10.1029/2008 GL033697

Larson D (2012) Runaway Devils Lake. Am Sci 100:46-53

> Mason IM, Guzkowska MAJ, Rapley CG, Street-Perrott FA (1994) The response of lake levels and areas to climatic change. Clim Change 27:161-197

> McCabe GJ Jr (1996) Effects of winter atmospheric circulation on temporal and spatial variability in annual streamflow in the western United States. Hydrol Sci J 41: 873-887

McCabe GJ Jr, Wolock DM (2002) Trends and temperature sensitivity of moisture conditions in the conterminous United States. Clim Res 20:19-29

McGowan HA, Sturman AP (1996) A hydrometeorological approach to the forecasting of inflows to alpine lakes. Phys Geogr 17:513-533

Meybeck M (2003) Global analysis of river systems: from Earth system controls to Anthropocene syndromes. Philos Trans R Soc Lond B 358:1935-1955

> Micklin P (2007) The Aral Sea disaster. Annu Rev Earth Planet Sci 35:47-72

> Mohammed IN, Tarboton DG (2011) On the interaction between bathymetry and climate in the system dynamics and preferred levels of the Great Salt Lake. Water Resour Res 47:W02525

North Dakota State Water Commission (2012) Devils Lake and Stump Lake area-capacity table. Available at http:// nd.water.usgs.gov/devilslake/pdf/elevation-area-volume. pdf (accessed 15 November 2012)

$>$ Peterson TC, Heim RR Jr, Hirsch R, Kaiser DP and others (2013) Monitoring and understanding changes in heat waves, cold waves, floods, and droughts in the United States. Bull Am Meteorol Soc 94:821-834

Petrow T, Zimmer J, Merz B (2009) Changes in the flood hazard in Germany through changing frequency and persistence of circulation patterns. Nat Hazards Earth
Syst Sci 9:1409-1423

Quiring SM, Goodrich GB (2008) Nature and causes of the 2002 to 2004 drought in the southwestern United States compared with the historic 1953 to 1957 drought. Clim Res 36:41-52

Raymond PA, Oh NH, Turner RE, Broussard W (2008) Anthropogenically enhanced fluxes of water and carbon from the Mississippi River. Nature 451:449-452

Rosenberg NJ (1986) Climate of the Great Plains region of the United States. Great Plains Q 7:22-32

Schilling KE, Chan KS, Liu H, Zhang YK (2010) Quantifying the effect of land use land cover change on increasing discharge in the Upper Mississippi River. J Hydrol 387 : 343-345

Sethre PR, Rundquist BC, Todhunter PE (2005) Remote detection of prairie pothole ponds in the Devils Lake Basin of North Dakota. GISc Remote Sens 42:277-296

Sheridan S (2002) The redevelopment of a weather-type classification scheme for North America. Int J Climatol 22:51-68

Sheridan S (2003) North American weather-type frequency and teleconnection indices. Int J Climatol 23:27-45

Smith AB, Katz RW (2013) US billion-dollar weather and climate disasters: data sources, trends, accuracy and biases. Nat Hazards 67:387-410

Stoner JD, Lorenz DL, Goldstein RM, Brigham ME, Cowdery TK (1998) Water quality in the Red River of the North basin. US Geological Survey 1169. US Geological Survey, Denver, CO

Todhunter PE (2001) A Hydroclimatological analysis of the Red River of the North snowmelt flood catastrophe of 1997. J Am Water Resour Assoc 37:1263-1278

- Todhunter PE (2012) Uncertainty of the assumptions required for estimating the regulatory flood: Red River of the North. J Hydrol Eng 17:1011-1020

> Tomer MD, Schilling KE (2009) A simple approach to distinguish land-use and climate-change effects on watershed hydrology. J Hydrol 376:24-33

Twine TE, Kucharik CJ, Foley JA (2004) Effects of land cover change on the energy and water balance of the Mississippi River Basin. J Hydrometeorol 5:640-655

US Geological Survey (2012) USGS Water Data for the Nation web page. Available at http://waterdata.usgs.gov/ nwis/ (accessed 15 November 2012)

- Vanos JK, Cakmak S (2014) Changing air mass frequencies in Canada: potential links and implications for human health. Int J Biometeorol 58:121-135

Wiche G (1986) Hydrologic and climatologic factors affecting water levels of Devils Lake, North Dakota. WaterResources Investigations Report 86-4320. US Geological Survey Bismarck, ND

Wilby RL (1993) The influence of variable weather patterns on river water quantity and quality regimes. Int J Climatol 13:447-459

- Williams WD (1996) What future for saline lakes? Environment 38:12-20, 38-39

Williams WD (2002) Environmental threats to salt lakes and the likely status of inland saline ecosystems in 2025. Environ Conserv 29:154-167

Zhang YK, Schilling KE (2006) Increasing streamflow and baseflow in Mississippi River since the 1940s: effect of land use change. J Hydrol 324:412-422

Submitted: December 17, 2013; Accepted: July 14, 2014

Proofs received from author(s): September 23, 2014 